\title{
Anaerobic and Aerobic Transformations Affecting Stability of Dewatered Sludge during Long-Term Storage in a Lagoon
}

\author{
Irina Lukicheva ${ }^{1}$, Guanglong Tian $^{2}$, Albert Cox²$^{2}$, Thomas Granato ${ }^{2}$, Krishna Pagilla ${ }^{1 *}$
}

\begin{abstract}
The goal of this work was to study long-term behavior of anaerobically digested and dewatered sludge (biosolids) in a lagoon under anaerobic and aerobic conditions to determine the stability of the final product as an indicator of its odor potential. Field lagoons were sampled to estimate spatial and temporal variations in the physicalchemical properties and biological stability characteristics such as volatile solids content, accumulated oxygen uptake, and soluble protein content and odorous compound assessment. The analyses of collected data suggest that the surface layer of the lagoon (depth of above $0.15 \mathrm{~m}$ ) undergoes long-term aerobic oxidation resulting in a higher degree of stabilization in the final product. The subsurface layers (depth $0.15 \mathrm{~m}$ below the surface and deeper) are subjected to an anaerobic environment where the conditions favor the initial rapid organic matter degradation within approximately the first year, followed by slow degradation. Water Environ. Res., 84, 17 (2012).
\end{abstract}

KEYWORDS: Lagoon aging, sludge, biosolids stability, odor potential, Class A.

doi:10.2175/106143011X13184214855975

\section{Introduction}

Disposal of wastewater sludge in an environmentally safe manner represents a great challenge for wastewater treatment plants (WWTPs) in the United States and around the world. Use of treated biosolids for land application allows for recycling of the high nutrient value of the biosolids product. Under the U.S. Environmental Protection Agency's Part 503 Sludge Reuse and Disposal Regulations, specific levels of treatment of sludge are required for deactivation of pathogens before land application (U.S. EPA, 1993a). Sludge processing often requires high energy use and involves high operational costs to achieve a more advanced level of biosolids treatment, such as Class A. Biosolids storage or aging as a post-treatment to anaerobic digestion is a low-cost conventional technology that has been shown to result in significant reductions in pathogens and indicator organisms. Tata et al. (2000) showed that storage of dewatered biosolids in aging lagoons helps to achieve $2.18 \mathrm{log}$ inactivation

\footnotetext{
${ }^{1}$ Department of Civil, Architectural and Environmental Engineering, Illinois Institute of Technology, Chicago, Illinois.

${ }^{2}$ Monitoring and Research Department, Metropolitan Water Reclamation District of Greater Chicago, Cicero, Illinois.

*Department of Civil, Architectural and Environmental Engineering, Illinois Institute of Technology, 3201 S Dearborn Street, Chicago, IL 60616, USA; e-mail: pagilla@iit.edu.
}

in fecal coliform density and 1.36 log inactivation in Salmonella density within 1.5 years of aging. Reimers et al. (1990) and Nelson et al. (2004) also demonstrated pathogen inactivation over a long period of sludge storage in anaerobic lagoons. Metropolitan Water Reclamation District of Greater Chicago (District) has been operating lagoon aging and air drying as a post-treatment to mesophilic anaerobic digestion for more than 10 years. This process of lagoon aging and drying results in Class A final biosolids product under U.S. EPA 40 CFR Part 503 Alternative 4 (USEPA, 1993a, Tata et al., 2003). Although aged biosolids can be land applied without restriction because of their exceptional quality, they can still produce odors when rewetted or stockpiled. Because of potential for odors, the air-dried biosolids cannot be stored for an extended period to be used under various options with minimal odor nuisance. Davis et al. (2008), Higgins et al. (2008), and Rosenfeld and Suffet (2004) demonstrated that the most common odorants in anaerobically digested sludges are volatile sulfur compounds (VSCs) that result from the degradation of sulfur-containing proteins in anaerobic environments. Potential for odor production from the biosolids is directly related to their stability, which increases with the breakdown of readily decomposable organics in the substrate and the formation of slowly decomposable humus (Switzenbaum et al., 1997). Highly stable biosolids have some degradable organic compounds present, but these compounds decompose at a much slower rate compared to the original organic matter. Production of biosolids that show low or no odor largely depends on the degree of organic matter stabilization in the lagoons. In addition to studies on pathogen reduction in the solids processing train discussed above, organic matter transformations and degradation during each step of biosolids processing are important to the quality of the final biosolids product.

Sludge treatment lagoons were described in several studies by Nelson et al. (2004), Paing et al. (2000), and Schneiter et al. (1993). Most of those studies pertain to aerobic, facultative, or anaerobic wastewater treatment lagoons. To date, none of this work has addressed use of lagoons for the stabilization of organic matter in anaerobically digested biosolids. Information regarding the changes in physical-chemical properties and biological activity indicators in biosolids according to aging time and location in the lagoon is essential for the development of better biosolids handling practices. Improved handling could advance the degree of stabilization of the material and reduce the potential for odor development. 
Table 1-Characteristics of high-solids lagoons at Metropolitan Water Reclamation District of Greater Chicago (sampled in October 2009).

\begin{tabular}{|c|c|c|c|c|c|}
\hline Lagoon number & Start of filling & End of filling & $\begin{array}{l}\text { Age of solids for the time } \\
\text { of sampling (months } \\
\text { since last filling) }\end{array}$ & Surface area $\left(\mathrm{m}^{2}\right)$ & Depth (m) \\
\hline 27 & Sep-07 & Jun-08 & 16.8 & 44111 & 6.7 \\
\hline 29 & Nov-08 & May-09 & 5.8 & 47753 & 6.4 \\
\hline
\end{tabular}

Because of the limited number of studies dealing with lagoon stabilization of biosolids, methods for determining the stability of lagoon-aged biosolids were selected from studies of anaerobically treated and composted sludges. For anaerobically treated wastes, volatile solids content is a widely used measurement of total organic matter. This indicator does not, however, necessarily reflect the nature of the material and its potential for biodegradability (Ponsa et al., 2010). Among other stability indicators used in the studies of composts or biological wastes, respirometric activity is the most typically used indicator of microbial activity (Barrena et al., 2009). Schievano et al. (2008) demonstrated that an oxygen uptake rate (OUR) assay in combination with volatile solids data can be useful to evaluate the performance of the anaerobic digestion process. In addition to microbial activity, biosolids also can be compared in terms of availability of substrate for microbial degradation. Bioavailable (soluble) protein in biosolids was demonstrated to have a strong correlation with the formation of odorous VSCs (Adams et al., 2004). Long-term storage in the lagoon is hypothesized to promote the degradation of soluble proteins over time, decreasing the potential for odor development. Therefore, analysis of bioavailable protein and direct measurement of odorous compounds from stored biosolids could also serve as indicators of the degree of stability.

The goal of the current study was to assess the stabilization of organic matter in dewatered biosolids during long-term lagoon storage for District lagoons as measured by the physical and chemical properties of biosolids and potential further biodegradability. Although lagoon storage of biosolids is a typically used practice at WWTPs, the District is the only known facility that uses an aging process under codified operations to produce Class A biosolids, especially at such a large scale. Thus, this study provides valuable information about processes of this nature.

\section{Materials and Methods}

The District's Class A high-solids process train involves four steps: mesophilic anaerobic digestion, conditioning with addition of high-molecular weight cationic polymer and centrifuge dewatering, lagoon-aging, and air-drying. Dewatered biosolids with approximately 20 to $30 \%$ total solids are transported $13 \mathrm{~km}$ by rail from the Stickney Water Reclamation Plant (WRP), Cicero, Illinois, and placed into lagoons. Pathogen inactivation and further product stabilization occur during a minimum period of 18 months of lagoon-aging. During this period, no additional biosolids are loaded into the lagoon. Water/drainage because of precipitation or because of solid-liquid separation is drained from the lagoons and recycled to the Stickney WRP.

Two lagoons (27 and 29) were studied during this research (Table 1). Lagoon 29 was operated as temporary storage for biosolids to be used for farmland application as Class B biosolids, which have less restrictive pathogen standard requirements compared to Class A biosolids (U.S. EPA, 1993a). At the time of sampling, the biosolids were aged in Lagoon 29 for approximately 6 to 12 months. Biosolids had last been added to Lagoon 27 approximately 17 months before commencement of this research. At the time of sampling, the surface of Lagoon 27 was covered with vegetation. Lagoon 27 was selected for sampling and analysis as a representative lagoon because it was full and already aged for the minimum of 17 months.

High-solids lagoons are loaded with digested and dewatered sludge with an average of 23 to $25 \%$ total solids. At this total solids content, biosolids do not possess the properties of fluid. As a result, biosolids placed from rail cars into the lagoon during loading will not distribute across the entire lagoon basin before additional loads are placed on top. Therefore, uniform stratification cannot be assumed, and the age of the solids is most likely dependent on both the depth and the location across the lagoon.

Sampling Procedures. The sampling locations in Lagoon 27 are shown in Figure 1. Because of the pattern of solids distribution described above, Lagoon 27 was sampled along the sides perpendicular to the loading edge of the lagoon (north and south sides). The two sides were considered as replicates. Five sampling points (T1 to T5) were chosen along each side, and core samples were taken at five depths (D1 to D5), resulting in 50 samples for the lagoon. The depths of biosolids sampled in Lagoon 27 were: 0 to $0.15 \mathrm{~m}, 0.15$ to $0.45 \mathrm{~m}, 0.45$ to $0.75 \mathrm{~m}, 0.75$ to $1.35 \mathrm{~m}$, and $1.35 \mathrm{~m}$ to bottom. The total depth of the biosolids at most of the sampling locations in Lagoon 27 was approximately $2 \mathrm{~m}$. For those locations where the depth of biosolids was more than $2 \mathrm{~m}$, the D5 depth interval was $1.35 \mathrm{~m}$ to the bottom. Each sampling point was located approximately 8 to $10 \mathrm{~m}$ from the side of the lagoon. A multisampler developed by Eijkelkamp, Netherlands, was used to take the core sample at each point and at different depths. This sampler allows relatively intact core samples to be taken from the layered strata of biosolids. It also allowed for the sampling of a lower layer of biosolids without contamination of an upper layer of the sample core. The sampler was injected into the lagoon by the sampling crew from the suspended crane workbox. Three cores were taken at each depth of a sampling point to form one composite sample.

Lagoon 29 was not completely filled, and the average depth of biosolids in this lagoon was shallower than Lagoon 27. Sampling of Lagoon 29 was performed at two locations, with the thickest depth at four depths intervals (same as D1 to D4 for Lagoon 27, where D4 was $0.75 \mathrm{~m}$ to the bottom), making a total of 8 samples. Thickest depths were chosen because their depth profiles most likely reflect the wider span of biosolids aging time in Lagoon 29. 


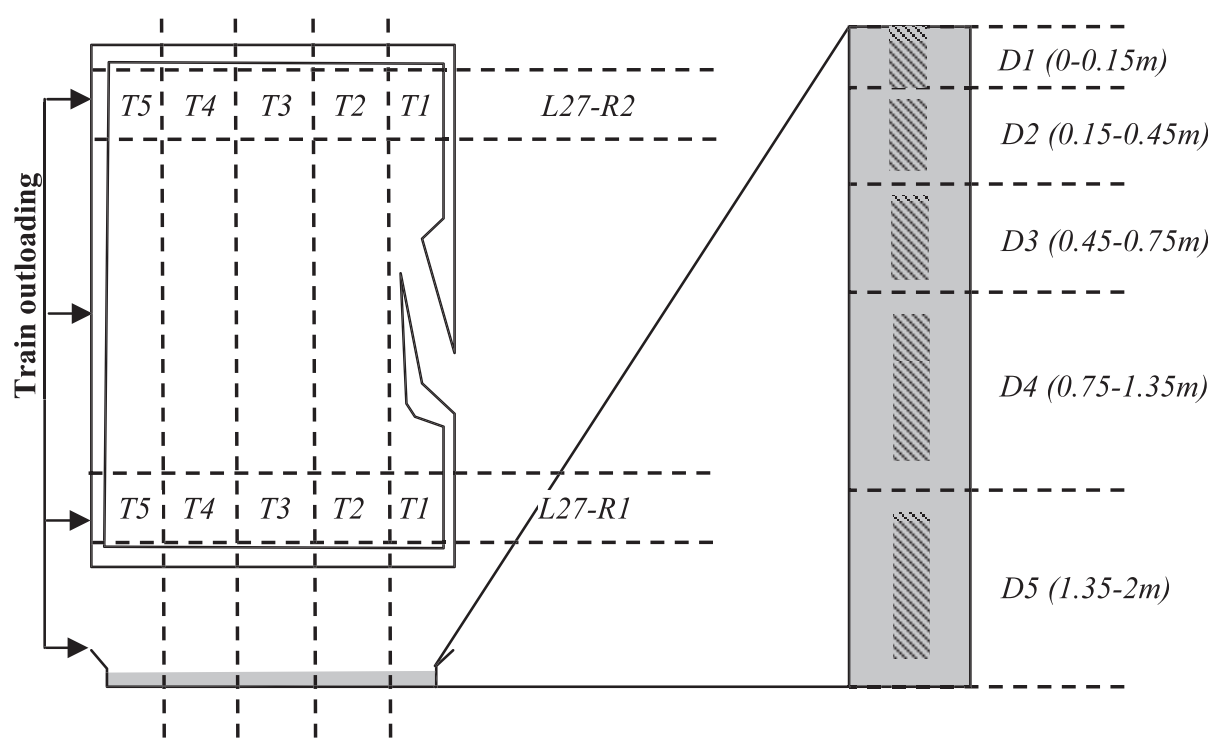

Indicates approximate core sample location

Figure 1-Schematic of Lagoon 27 showing depths and transects of sampling.

To evaluate changes in biosolids properties during lagoon aging, the initial characteristics of dewatered biosolids loaded into the lagoons was obtained from Stickney WRP operating reports (Table 2). The data in Table 2 shows the mean values of the analytical results of biosolids placed in the lagoons during the entire loading period. Because of the long period of lagoon loading (more than 6 months), collected samples could not be assigned to the exact months of placement into lagoon, thus the mean values of total solids and volatile solids were calculated over the entire loading period of the lagoons. Fresh dewatered biosolids composite grab samples were taken five times for one month from the Stickney WRP centrifuge conveyor belts. Those samples were also used as a reference for biosolids that have not been subjected to aging.

Table 2-Average values of analyses of centrifuge-dewatered biosolids loaded into Lagoons 27 and 29 (TKN = total Kjeldahl nitrogen; ACCOU20 = accumulated oxygen uptake after 20 hours; $B S A=$ bovine serum albumin).

\begin{tabular}{lc}
\hline Parameter & Average value \\
\hline Total solids (\%) Lagoon 27 & $25.1^{\mathrm{a}}$ \\
Total solids (\%) Lagoon 29 & $24.7^{\mathrm{a}}$ \\
Volatile solids (\% total solids) & \\
$\quad$ Lagoon 27 & $53.6^{\mathrm{a}}$ \\
Volatile solids (\% total solids) & \\
$\quad$ Lagoon 29 & $54.4^{\mathrm{a}}$ \\
$\mathrm{pH}$ & $8.0^{\mathrm{b}}$ \\
Ammonia-N (mg/g) & $10^{\mathrm{b}}$ \\
Nitrate/nitrite- N (mg/g) & $<0.05^{\mathrm{b}}$ \\
TKN (\% total solids) & $4.6^{\mathrm{b}}$ \\
ACCOU20 (mgO $/ \mathrm{g})$ & $35^{\mathrm{b}}$ \\
Soluble protein (mg BSA equiv/g) & $36^{\mathrm{b}}$ \\
\hline
\end{tabular}

${ }^{a}$ Data from the Stickney Water Reclamation Plant reports.

${ }^{\mathrm{b}}$ Average values for samples of centrifuge cake.
Sample Handling and Storage. All samples were transferred on ice to the laboratory and stored at $4{ }^{\circ} \mathrm{C}$ until analysis. Approximately $200 \mathrm{~g}$ of each sample was air-dried and ground for analyses that require a dry sample.

Analytical Methods. Total and volatile solids analyses were conducted according to Standard Methods (APHA et al., 2005). Total solids content was determined by drying the biosolids samples at 103 to $105{ }^{\circ} \mathrm{C}$. Volatile solids were determined as further loss in mass at $550{ }^{\circ} \mathrm{C}$. Volatile solids \% reduction (VSR) was calculated using the equation:

$\mathrm{VSR}=\left(1-\frac{\left(100 \%-\mathrm{VS}_{\mathrm{DS}}\right) \times\left(\frac{\mathrm{VS}_{\mathrm{L}}}{100 \%-\mathrm{VS}_{\mathrm{L}}}\right)}{\mathrm{VS}_{\mathrm{DS}}}\right) \times 100 \%$

Where

$$
\begin{aligned}
\mathrm{VS}= & \text { volatile solids }=\text { percentage of total solids in the } \\
& \text { sample } \\
\mathrm{DS}= & \text { dewatered biosolids, and } \\
\mathrm{L}= & \text { lagoon biosolids. }
\end{aligned}
$$

The $\mathrm{pH}$ and electrical conductivity were measured in a water suspension of centrifuged biosolids. The total Kjeldahl nitrogen (TKN) was measured using Kjeldahl digestion method followed by colorimetric analysis. Ammonia-N and nitrate+nitrite- $\mathrm{N}$ were determined in a water extraction using colorimetric analyses according to U.S. EPA methods 350.1 and 353.2, respectively (U.S. EPA, 1993b). All of the analyses were performed in duplicate.

Oxygen uptake was measured using BI-1000 Electrolytic Respirometer (BioScience Inc., Bethlehem, Pennsylvania) ( $\mathrm{T}=$ $25{ }^{\circ} \mathrm{C}$ and oxygen generation rate $=40 \mathrm{mg} / \mathrm{h}$ ). Biosolids samples were suspended in distilled water at $1 \%$ total solids slurry of approximately $1000 \mathrm{ml}$. The slurry was mixed with the homogenizer for two minutes and transferred into the reactor 
bottles (triplicates for each sample). The tests were run for 22 hours. Accumulated oxygen uptake after 20 hours (ACCOU20) was chosen for sample comparison.

Water soluble protein content was measured using the Lowry et al. (1951) method as described by Frølund et al., (1996). Bovine serum albumin (BSA) was used as the standard. Calibration was performed in the range of 0 to $0.5 \mathrm{mg} \mathrm{BSA} / \mathrm{L}$. Lerch et al. (1993) protein water extraction methodology was modified as follows: $5 \mathrm{~g}$ of biosolids sample were added to distilled water to make up $50 \mathrm{ml}$ of final volume. The suspension was mixed for two hours using a magnetic stirrer and centrifuged at $3000 \mathrm{~g}$ for 25 minutes at $5{ }^{\circ} \mathrm{C}$ (the centrifugation parameters were chosen according to Hall et al., 1996). As part of the Lowry method, protein concentrations of the formed supernatant were determined from absorbance at $750 \mathrm{~nm}$. The analyses were performed in triplicates.

The headspace storage test was used to determine the production of odorous compounds. The method described by Glindemann et al. (2006) was adjusted as follows. The samples were held for 60 days in airtight $125-\mathrm{mL}$ polyethylene terephthalate (PET) bottles (volume ratio sample/bottle was kept at least 20\%). Odorous VSCs measured were dimethyl sulfide (DMS) and dimethyl disulfide (DMDS). The headspace concentrations were measured using gas chromatography (GC)/ surface acoustic wave mass detection with $\mathrm{zNose}^{\mathrm{TM}}$ analyzer (Electronic Sensor Technology, Newbury Park, California). The inlet needle of the gas chromatograph was inserted into the headspace of the sample bottle for each measurement. The instrument was calibrated using high-sensitivity settings. The detection limits were $0.08 \mathrm{ppm}$ for DMS and $0.005 \mathrm{ppm}$ for DMDS.

Statistical Analysis. The total solids, volatile solids, pH, electrical conductivity, TKN, ammonia, and ACCOU20 data showed normal distribution; thus, analysis of variance (ANOVA), and least significant difference (LSD) post-hoc tests were conducted to study the significance of the differences within those parameters. Statistical tests were carried out using SPSS 16.0 (SPSS Inc, Chicago, Illinois).

\section{Results}

To understand how measured parameters varied within the lagoons, the results from the analyses of those parameters were presented in the form of characteristic profiles of each of the studied parameters throughout the lagoons. The profiles of the measured parameters according to depth and location within the lagoons are discussed in the following sections.

Physical and Chemical Properties. The total solids, pH, and electrical conductivity profiles in the Lagoon 27 biosolids are shown in Table 3. The surface layer of Lagoon 27 (top $0.15 \mathrm{~m}$ ) was significantly (significance $<0.05$ ) different from the layers below. Total solids in the biosolids of the surface layer ranged from 37.5 to $42.1 \%$. This range likely is because of the variability of distribution of runoff water caused by precipitation or snowmelt on the top of the lagoon. In the subsurface layers (below $0.15 \mathrm{~m}$ ), the total solids content of biosolids remained between 18 and 23\%, which was close to the total solids content of the dewatered biosolids that were loaded into the lagoon. The data in Table 3 show that solids contents in the deeper layers were lower, but not significantly different from each other (significance $>0.05$ ). The gradient from lower solids content in
Table 3-Average values of total solids, $\mathrm{pH}$, and electrical conductivity in biosolids throughout the profile of Lagoon 27.

\begin{tabular}{|c|c|c|c|c|c|c|}
\hline \multirow{2}{*}{$\begin{array}{l}\text { Location } \\
\text { Depth } \\
\text { intervals (m) }\end{array}$} & \multicolumn{5}{|c|}{$\begin{array}{l}\text { Distance from loading side of Lagoon } 27(\mathrm{~m}) \\
\text { (total width of lagoon is } 160 \mathrm{~m} \text { ) }\end{array}$} & \multirow[b]{2}{*}{ Legend } \\
\hline & 10 & 45 & 80 & 115 & 150 & \\
\hline \multicolumn{7}{|c|}{ Total solids (\%) } \\
\hline $0-0.15$ & 39.2 & 38.6 & 39.8 & 37.4 & 42.1 & $18-19$ \\
\hline $0.15-0.45$ & 23.1 & 23.1 & 22 & 23.3 & 22.7 & 19-20 \\
\hline $0.45-0.75$ & 20.4 & 20.3 & 20.4 & 20.3 & 20.6 & 20-21 \\
\hline $0.75-1.35$ & 19.6 & 19.6 & 19.5 & 19.7 & 19.4 & $21-24$ \\
\hline $1.35-2$ & 18.7 & 18.9 & 18.6 & 19.1 & 18.1 & $>24$ \\
\hline \multicolumn{7}{|l|}{$\mathrm{pH}$} \\
\hline $0-0.15$ & 6.1 & 6 & 6.3 & 6.2 & 6.2 & $6-7$ \\
\hline $0.15-0.45$ & 8.0 & 8.3 & 7.7 & 7.8 & 8.0 & $7-7.5$ \\
\hline $0.45-0.75$ & 8.3 & 8.2 & 8.4 & 7.7 & 8.2 & $7.5-8$ \\
\hline $0.75-1.35$ & 8.7 & 8.2 & 8.5 & 7.8 & 8.1 & $8-8.5$ \\
\hline $1.35-2$ & 8.7 & 8.3 & 8.4 & 7.9 & 7.9 & $8.5-9$ \\
\hline \multicolumn{7}{|c|}{ Electrical conductivity $(\mathrm{mS} / \mathrm{cm})$} \\
\hline $0-0.15$ & 3.6 & 3.6 & 3.0 & 1.8 & 3.2 & $<6$ \\
\hline $0.15-0.45$ & 10.1 & 11.4 & 9.1 & 6.5 & 7.1 & $6-8$ \\
\hline $0.45-0.75$ & 11.5 & 13.2 & 11.1 & 6.9 & 8.6 & $8-10$ \\
\hline $0.75-1.35$ & 10.3 & 12.2 & 10.8 & 7.6 & 8.5 & $10-12$ \\
\hline $1.35-2$ & 11.5 & 12.5 & 8.2 & 7.3 & 8.1 & $>12$ \\
\hline
\end{tabular}

lower layers of the lagoon to higher solids content in the upper layers apparent from Table 3 is most likely because of the combination of drainage of water to the bottom of the lagoon and evapotranspiration from the surface.

The $\mathrm{pH}$ of the biosolids was constant throughout the four subsurface layers in Lagoon 27, with average values of 7.7 to 8.7. Biosolids of the surface layer of the lagoon had $\mathrm{pH}$ values from 6 to 6.2 , which was significantly lower than for the subsurface layer biosolids (significance $<0.05$ ).

The electrical conductivity profiles of biosolids throughout Lagoon 27 had similar trends as total solids and pH. Surface layer biosolids had significantly lower values of electrical conductivity, while subsurface layer electrical conductivity values did not vary significantly throughout the depths (significance $<0.05$ ). The $\mathrm{pH}$ and electrical conductivity profiles demonstrated that solids located $115 \mathrm{~m}$ from the loading side had lower values for both parameters (Table 3).

The TKN and ammonia biosolids profiles throughout Lagoon 27 biosolids were also dependent on depth throughout the lagoon profile (Table 4). In the subsurface layers of the lagoon, TKN and ammonia concentrations in the biosolids were higher than those in the surface layer. The TKN concentration in the subsurface layers varied between 3.32 and 5.02\%; ammonia-N content was between 10 and $20 \mathrm{mg} / \mathrm{g}$. In the biosolids of the surface layer, TKN concentrations were between 2.37 to $3.09 \%$, and ammonia content was less than $1 \mathrm{mg} / \mathrm{g}$. Comparing these concentrations to the initial TKN concentrations in the dewatered biosolids (approximately 4.6\%), it can be concluded that in the subsurface layers, solids TKN content did not change significantly, while in the surface layer, TKN content in the biosolids decreased.

The variation in TKN and ammonia- $\mathrm{N}$ in biosolids across Lagoon 27 in the direction of loading indicated that the loading 
Table 4-Average values of total Kjeldahl nitrogen (TKN), ammonia- $\mathrm{N}$, and nitrate- $\mathrm{N}$ in biosolids throughout the profile of Lagoon 27.

\begin{tabular}{|c|c|c|c|c|c|c|}
\hline \multirow{2}{*}{$\begin{array}{l}\text { Location } \\
\text { Depth } \\
\text { intervals (m) }\end{array}$} & \multicolumn{5}{|c|}{$\begin{array}{l}\text { Distance from loading side of Lagoon } 27(\mathrm{~m}) \\
\text { (total width of lagoon is } 160 \mathrm{~m} \text { ) }\end{array}$} & \multirow[b]{2}{*}{ Legend } \\
\hline & 10 & 45 & 80 & 115 & 150 & \\
\hline \multicolumn{7}{|c|}{ TKN (\% total solids) } \\
\hline $0-0.15$ & 2.71 & 3.09 & 2.81 & 2.37 & 2.78 & $4.5-5$ \\
\hline $0.15-0.45$ & 4.55 & 4.53 & 3.32 & 3.46 & 4.02 & $4-4.5$ \\
\hline $0.45-0.75$ & 4.64 & 4.96 & 3.84 & 3.56 & 4.38 & $3.5-4$ \\
\hline $0.75-1.35$ & 4.60 & 5.01 & 4.00 & 3.88 & 4.32 & $3-3.5$ \\
\hline $1.35-2$ & 4.83 & 5.02 & 4.02 & 3.93 & 4.34 & $<3$ \\
\hline \multicolumn{7}{|c|}{ Ammonia-N (mg/g) } \\
\hline $0-0.15$ & 0.4 & 0.2 & 1.4 & 0.003 & 0.006 & $>16$ \\
\hline $0.15-0.45$ & 13.1 & 16.1 & 10.8 & 8.3 & 10.9 & $12-16$ \\
\hline $0.45-0.75$ & 14.9 & 18.0 & 20.1 & 9.1 & 13.7 & $8-12$ \\
\hline $0.75-1.35$ & 14.8 & 18.3 & 15 & 9.6 & 13.3 & $2-8$ \\
\hline $1.35-2$ & 16.5 & 17.8 & 12.8 & 9.4 & 12.1 & $<2$ \\
\hline \multicolumn{7}{|c|}{ Nitrate-N (mg/g) } \\
\hline $0-0.15$ & 1.92 & 1.66 & 0.46 & 0.19 & 0.57 & $>1$ \\
\hline $0.15-0.45$ & 0.004 & 0.02 & 0.16 & 0.11 & 0.03 & $0.1-1$ \\
\hline $0.45-0.75$ & 0.01 & 0.01 & 0.01 & 0.02 & 0.02 & $0.01-0.1$ \\
\hline $0.75-1.35$ & 0.004 & 0.004 & 0.02 & 0.01 & 0.01 & $<0.01$ \\
\hline $1.35-2$ & 0.003 & 0.003 & 0.01 & 0.01 & 0.01 & \\
\hline
\end{tabular}

side concentrations of those compounds were higher than the opposite side of the lagoon.

Nitrate- $\mathrm{N}$ content profiles exhibited trends opposite to ammonia. As demonstrated in Table 4, concentrations in biosolids from subsurface layers were negligible; in the surface layer, concentration ranged between 0.19 to $1.9 \mathrm{mg} / \mathrm{g}$.

In Lagoon 29, there were no significant differences in properties between those profiles and within the depths. Average values of all studied parameters averaged for all depths are presented in Table 5. The average values of total solids, $\mathrm{pH}$, electrical conductivity, TKN, ammonia- $\mathrm{N}$, and nitrate/nitrite-N in biosolids of Lagoon 29 are similar to the average values of those parameters in the biosolids of the subsurface layers of Lagoon 27.

Biodegradability Indicators. The volatile solids in biosolids at different locations and depths in Lagoon 27 are shown in Table 6. Volatile solids concentrations in the surface layer were

Table 5-Average values of analyses of biosolids at four depths of Lagoon 29 (TKN = total Kjeldahl nitrogen; BSA = bovine serum albumin).

\begin{tabular}{lc}
\hline Parameter & Average value \\
\hline Total solids (\%) & 25 \\
Volatile solids (\% total solids) & 43 \\
$\mathrm{pH}$ & 8.2 \\
Electrical conductivity (mS/cm) & 13.8 \\
Ammonia-N (mg/g) & 10.2 \\
Nitrate/nitrite- N (mg/g) & $<0.05$ \\
TKN (\% total solids) & 4.2 \\
ACCOU20 (mg $\left.\mathrm{m}_{2} / \mathrm{g}\right)$ & 4.4 \\
Soluble protein $(\mathrm{mg}$ BSA equiv/g) & 24 \\
\hline
\end{tabular}

Table 6-Average values of volatile solids, accumulated oxygen uptake after 20 hours (ACCOU20), and protein levels in biosolids throughout the profile of Lagoon 27 (BSA = bovine serum albumin).

\begin{tabular}{|c|c|c|c|c|c|c|}
\hline \multirow{2}{*}{$\begin{array}{l}\text { Location } \\
\text { Depth } \\
\text { intervals (m) }\end{array}$} & \multicolumn{5}{|c|}{$\begin{array}{l}\text { Distance from loading side of Lagoon } 27(\mathrm{~m}) \\
\text { (total width of lagoon is } 160 \mathrm{~m} \text { ) }\end{array}$} & \multirow[b]{2}{*}{ Legend } \\
\hline & 10 & 45 & 80 & 115 & 150 & \\
\hline \multicolumn{7}{|c|}{ Volatile solids (\% total solids) } \\
\hline $0-0.15$ & 45.2 & 43.9 & 45.6 & 45.7 & 41.6 & $>48$ \\
\hline $0.15-0.45$ & 46.8 & 45.1 & 47.5 & 49.0 & 45.2 & $47-48$ \\
\hline $0.45-0.75$ & 47.7 & 45.5 & 48.1 & 49.7 & 45.6 & $46-47$ \\
\hline $0.75-1.35$ & 48.1 & 45.8 & 48.2 & 49.9 & 45.5 & $45-46$ \\
\hline $1.35-2$ & 48.3 & 45.8 & 47.0 & 49.5 & 45.6 & $41-45$ \\
\hline \multicolumn{7}{|c|}{ Accou20 ( $\mathrm{mgO}_{2} / \mathrm{g}$ total solids) } \\
\hline $0-0.15$ & 3.9 & 3.9 & 3.3 & 1.8 & 2.8 & $>6$ \\
\hline $0.15-0.45$ & 4.5 & 5.2 & 5.7 & 5.4 & 6.1 & $5-6$ \\
\hline $0.45-0.75$ & 5.5 & 4.9 & 4.2 & 3.8 & 6.1 & $4-5$ \\
\hline $0.75-1.35$ & 5.9 & 4.1 & 6.1 & 5.0 & 7.6 & $3-4$ \\
\hline $1.35-2$ & 6.8 & 4.5 & 4.4 & 7.3 & 8.4 & $<3$ \\
\hline \multicolumn{7}{|c|}{ Protein (mg BSA equiv/g total solids) } \\
\hline $0-0.15$ & 6.7 & 4.7 & 4.5 & 5.2 & 4.6 & $>25$ \\
\hline $0.15-0.45$ & 22.2 & 20.0 & 15.1 & 9.8 & 15.4 & $20-25$ \\
\hline $0.45-0.75$ & 26.9 & 31.4 & 35.1 & 11.8 & 18.7 & $15-20$ \\
\hline $0.75-1.35$ & 14.8 & 30.1 & 23.3 & 13.4 & 21.0 & $7-15$ \\
\hline $1.35-2$ & 25.4 & 21.3 & 23.4 & 18.6 & 16.0 & $<7$ \\
\hline
\end{tabular}

significantly different from those in the subsurface layers. In the subsurface layers (below $0.15 \mathrm{~m}$ ) of Lagoon 27, biosolids volatile solids values ranged from 44 to $50 \%$ and from 42 to $46 \%$ in the surface layer.

Because of the temporal and spatial variability of volatile solids concentrations in materials loaded to a lagoon, the mean of the volatile solids concentration in the loaded biosolids over the entire loading period was calculated as the initial volatile solids in biosolids in the lagoon. Based on plant operating reports, the dewatered biosolids loaded into Lagoon 27 had a mean volatile solids value of $53.6 \%$ (Table 2 ).

The volatile solids data for Lagoon 27 (Table 6) were consistent throughout the subsurface layers of the lagoon, and the difference in volatile solids concentration is pertinent only to biosolids in the surface layer. Overall, during aging, the volatile solids concentration of biosolids in Lagoon 27 decreased from $53.6 \%$ to approximately $47 \%$ in the subsurface layers and to $44 \%$ in the surface layer. Based on these data, the VSR for both layers is approximately 21 and 30\%, for the subsurface and surface layers, respectively.

For Lagoon 29, the volatile solids in biosolids did not vary with depth, and volatile solids decreased during storage from 54.4 to $42.9 \%$ total solids (Tables 2 and 5), resulting in total VSR of $37 \%$. Thus, storage of biosolids in Lagoon 29 resulted in a higher reduction in volatile solids than for both the surface and subsurface layers biosolids of Lagoon 27.

Oxygen uptake, represented as ACCOU20, and protein content were determined to further characterize microbial activity and bioavailability of the lagoon biosolids. Table 6 shows the profiles of ACCOU20 within Lagoon 27. The statistical difference between the means demonstrated that for 
the previously described parameters, the surface layer was significantly different from each of the subsurface layers (significance $<0.05$ ), and the ACCOU20 in the subsurface layers did not vary (significance $>0.05$ ). In comparison with the fresh dewatered biosolids, lagoon storage significantly reduced oxygen uptake for both the uppermost and the subsurface layers. The ACCOU20 averaged $35 \mathrm{mg} \mathrm{O} / \mathrm{g}$ total solids for unaged dewatered biosolids (Table 2). The oxygen uptake of lagooned biosolids was relatively low. The ACCOU20 of biosolids from the subsurface layers of Lagoon 27 ranged from 4 to $9 \mathrm{mg} \mathrm{O} / \mathrm{g}$ total solids, which was higher than for the surface layer biosolids, where ACCOU20 could be as low as $1.8 \mathrm{mg} \mathrm{O} / \mathrm{g}$ total solids (Table 6). The average ACCOU20 of biosolids from Lagoon 29 was $4.4 \mathrm{mg} \mathrm{O}_{2} / \mathrm{g}$ total solids (Table 6).

Table 6 demonstrates the spatial variation of soluble protein in biosolids within Lagoon 27. As for the previously described parameters, the surface layer biosolids had the lowest concentrations of soluble protein, which ranged from 4.48 to $6.69 \mathrm{mg}$ BSA equiv/g total solids. The subsurface layers concentration of protein ranged from 9.8 to $35.1 \mathrm{mg}$ BSA equiv/g total solids. In comparison, unaged dewatered biosolids values were, on

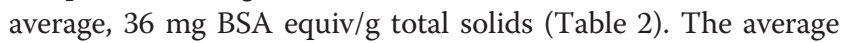
protein concentration in biosolids from Lagoon 29 was $25 \mathrm{mg}$ BSA equiv/g total solids (Table 6).

The analysis of all bioavailability parameters in Lagoon 27 did not indicate any specific trends following the loading pattern of the solids in the lagoon. Protein content decreased significantly (Significance $<0.05$ ) with distance from the loading side of the lagoon.

Odorous Compounds. Production of VSCs, especially hydrogen sulfide, methanethiol, DMS, and DMDS is considered the primary cause of odoriferous conditions in biosolids (Higgins et al., 2006). Although other compounds are also considered to contribute to odor formation, DMS and DMDS were chosen to be analyzed because of their low odor threshold levels. Rosenfeld and Suffet (2004) listed the DMS and DMDS air odor threshold to be 0.001 and 0.000026 ppmv, respectively. Headspace analyses of DMS and DMDS formed from stored lagoon samples did not indicate concentrations above the instrument detection limits (0.08 ppm for DMS and $0.005 \mathrm{ppm}$ for DMDS). Because the threshold limits for those compounds are lower than the instrument detection limits, the data for these compounds could not be correlated to odor potential. To measure lower concentrations of those compounds, a different methodology has to be implemented to collect air samples from biosolids headspace.

\section{Discussion}

Analysis of depth and spatial patterns for parameters used in this study indicated differences between the surface layer (above $0.15 \mathrm{~m}$ ) and the subsurface layers (below $0.15 \mathrm{~m}$ ) of Lagoon 27. The concentration profiles for nitrogen compounds demonstrated that in the subsurface layer, ammonia from dewatered biosolids was not oxidized. In the biosolids from the surface layer of Lagoon 27, however, ammonia- $\mathrm{N}$ levels were low, and nitrate- $\mathrm{N}$ concentrations were high. High nitrate-N/ammonia-N ratio suggested that in the surface layer, nitrification processes are taking place, and this stratification allows for differentiation between aerobic and anaerobic environments along the lagoon depth profile. The top $0.15 \mathrm{~m}$ of the Lagoon 27 could be considered aerobic, and the material in the surface layer could be assumed to undergo aerobic stabilization processing because of exposure to the atmosphere and weathering effects. In addition, the vegetation in the surface layer probably performed in a manner similar to a reed bed system in which oxygen transferred to the roots of the plants assists in the biological stabilization and mineralization of the biosolids (Tchobanoglous et al., 2002). The subsurface layers of the lagoon can be considered anaerobic, as shown by ammonia-N concentrations similar to the concentrations in the unaged dewatered biosolids (Table 2). The nitrate- $\mathrm{N}$ concentrations in the bottom layers were close to zero because conditions were not favorable for nitrification.

The difference between aerobic and anaerobic conditions among those layers was also reflected in the profiles of biodegradability indicators. As demonstrated in Table 6, the volatile solids levels in biosolids of Lagoon 27 were lowest in the surface layer. This could be explained by exposure to aerobic stabilization for a long period of time. Overall VSR in the subsurface layers was lower compared to the surface layers. The loading of Lagoon 27 spanned 10 months. It was hypothesized that the difference in the solids aging time would be reflected in the profiles of biodegradability parameters within the lagoon. The similarity in volatile solids in biosolids within the subsurface layers might suggest that stabilization of organic matter in the lagoon's anaerobic environment takes place slowly after the initial reduction that occurs in the first year of storage while the lagoon is being loaded. The conditions during the loading period were most likely similar to those in Lagoon 29. A similar phenomenon is described by Nelson et al. (2004) and Bryant and Rich (1984) for anaerobic sludges and sediments. They demonstrated that initial degradation of volatile solids in pond sediments occurs rapidly within the first year because of the presence of more easily hydrolysable organic matter. This rapid degradation is followed by continual slow degradation because of remaining organic matter that requires considerable processing before it is hydrolyzed and degraded further. Nelson et al. (2004) reported the initial rapid decrease in volatile solids to approximately 42 to $45 \%$ total solids from an initial value of 65 to $75 \%$. After that, further volatile solids reduction to approximately $36 \%$ of total solids needed more than six years of subsequent storage.

Stability indicators for biosolids from Lagoon 29 resemble subsurface layer biosolids of Lagoon 27 except for the volatile solids (Tables 3 to 6). Storage time of biosolids in Lagoon 29 was approximately 6 months, which resulted in approximately $38 \%$ volatile solids reduction. Therefore, although initial stabilization in the lagoon occurs rapidly, further stabilization in the subsurface proceeds slowly. The shallower depth in Lagoon 29 might have led to a relatively higher volatile solids reduction compared to that in Lagoon 27.

In addition to the characteristics of organic matter bioavailability, the slower anaerobic degradation rates might be because of conditions that developed in the lagoon. Anaerobic processes are sensitive to $\mathrm{pH}$. For example, a $\mathrm{pH}$ value near neutral is preferred for methanogens (Tchobanoglous et al., 2002). Lay et al. (1997) demonstrated that the process of methane production because of high-solids digestion at moisture contents of 90 to $96 \%$ functions over a $\mathrm{pH}$ range of 6.6 to 7.8 , with an optimum of 6.8 ; a $\mathrm{pH}$ lower than 6.1 or higher than 8.3 
could cause process failure. Nelson et al. (2004) measured pH in the anaerobic lagoons to be between 6.8 and 6.9. For those conditions, they demonstrated volatile solids reduction with the sludge age within the pond because of anaerobic degradation. Data in Table 3 shows that the $\mathrm{pH}$ level for solids in the subsurface layers of Lagoon 27 was between 7.7 and 8.7, which might suggest slower rates of methanogenic and overall anaerobic activity.

Besides $\mathrm{pH}$, other factors, such as temperature, can also significantly reduce anaerobic degradation. Rittmann and McCarty (2001) reported that BOD removal in an anaerobic lagoon attributable to methanogens drops significantly with a decrease in temperature below $15^{\circ} \mathrm{C}$. Schneiter et al. (1993) demonstrated little or no degradation of the volatile fraction of accumulated sludge in cold-climate lagoons over a storage period greater than 200 days. Chicago winter ambient temperatures below $0{ }^{\circ} \mathrm{C}$ can result in unfavorable conditions for anaerobic degradation.

Aging in the lagoon was shown to decrease respirometric activity and soluble protein concentrations in the biosolids to various extents for aerobic and anaerobic layers. Because of the long-term aerobic oxidation of the surface layer material in Lagoon 27, it was expected to have a more advanced degree of stabilization and lower respirometric activity than for the solids of the subsurface layers. As shown in Table 6, ACCOU20 for the solids of the surface aerobic layer was lower than for the solids of the subsurface anaerobic layers. Haug (1993) used an OUR of $20 \mathrm{mg} \mathrm{O} / 2 / \mathrm{kg}$ dissolved solids•h ( $0.02 \mathrm{mg} \mathrm{O} / \mathrm{g}$ total solids•h) to indicate stable compost. Lasaridi and Stentiford (1998) used a higher rate of $1 \mathrm{mg} \mathrm{O} / \mathrm{g}$ volatile solids•h (assuming volatile solids equals $50 \%$ of total solids as it approximates to $0.5 \mathrm{mg} \mathrm{O}_{2} /$ $\mathrm{g}$ total solids•h) as stable compost after maturation. For comparison, the OUR of biosolids within the 20 hours measured in this study ranged from 0.2 to $0.5 \mathrm{mg} \mathrm{O}_{2} / \mathrm{g}$ total solids•h for the anaerobic layers and 0.02 to $0.25 \mathrm{mg} \mathrm{O}_{2} / \mathrm{g}$ total solids•h for the aerobic layers (data not shown). Based on this information, materials from both the aerobic and anaerobic zones in the lagoon could be considered stable.

Concentrations of soluble proteins in biosolids in the anaerobic layers of Lagoon 27 and at all depths of Lagoon 29 were comparable to those reported by Adams et al. (2004) for postdigested material shown to be potentially odoriferous. In this study, odorous compounds, such as DMS and DMDS from the headspace test, were not detected. DMS can be formed and degraded either in aerobic or anaerobic environments; DMDS is produced from methanethiol oxidation. Both of these compounds are produced from biological degradation of sulfurcontaining proteins (Higgins et al., 2006; Lomans et al. 2002). Analysis of soluble proteins indicated that concentrations were high enough to potentially result in production of VSCs. Slow degradation of organic matter demonstrated by volatile solids reduction may indicate, however, that odorous compounds were forming at slow rates and, therefore, could not be detected with the method used for analysis.

As previously mentioned, the inability to detect DMS and DMDS from lagoon-aged biosolids does not necessarily mean that the biosolids do not have odor potential. Chen et al. (2006) demonstrated that other odorous compounds, such as volatile aromatics, might be responsible for odor generation. Because lagooned biosolids demonstrate low degradation rates, however, the headspace measurements of any odor-related compounds might not be possible. In addition, odors released during final biosolids use are associated with biosolids that were also processed by air drying after lagoon aging. The aerobic posttreatment of biosolids may result in further material decomposition at higher rates, resulting in the production of odorous compounds at higher concentrations.

\section{Conclusions}

Spatial and temporal analyses of biosolids characteristics, such as total solids, $\mathrm{pH}$, electrical conductivity, volatile solids, TKN, ammonia, nitrite, ACCOU20, and soluble protein suggested that degradation of organic matter in dewatered biosolids in the lagoons occurs in two environments at different rates. For lagoons aged more than 6 months, which are significantly infested with weeds on the surface, the top $0.15 \mathrm{~m}$ of the lagoon is subjected to aerobic oxidation resulting in more advanced biosolids stabilization. Stabilization of organic matter in the subsurface anaerobic zone (below $0.15 \mathrm{~m}$ ) could take place appreciably within the first year of aging and at a slow rate thereafter. The levels of VSCs in the headspace from samples taken from either one of those zones were below detection limits, and ACCOU20 indicates that even in the subsurface layer, the stability of the biosolids were similar to that observed for compost. Given that odoriferous conditions typically develop after biosolids are removed from the stockpiling of air-dried biosolids, other organic matter stabilization mechanisms may also be involved in the odor potential of biosolids.

\section{Acknowledgments}

Financial support for this research was provided by the Metropolitan Water Reclamation District of Greater Chicago. The authors would also like to thank Daniel Collins and Ann Ko at LASMA of the District's Maintenance and Operations (M\&O) Department for providing lagoon information, M\&O's Master Mechanics Section for providing heavy equipment for sampling operation in lagoons, and personnel of Analytical Laboratory Division and the Environmental Monitoring and Research Division for conducting some of the analyses and for providing biosolids monitoring data of initial volatile solid contents in biosolids. The authors are also grateful to the Wastewater Section for providing respirometers used in this research.

Manuscripts submitted for publication January 12, 2011; revised manuscript submitted March 3, 2011; accepted for publication May 12, 2011.

\section{References}

Adams, G. M. (2004) Identifying and Controlling Municipal Wastewater Odor Phase II. IWA Publishing: London, England, United Kingdom. American Public Health Association; American Water Works Association; Water Environment Federation (2005) Standard Methods for the Examination of Water \& Wastewater, 21st ed. American Public Health Association: Washington, D.C.; American Water Works Association: Denver, Colorado; Water Environment Federation: Alexandria, Virginia.

Barrena, R.; d’Imporzano, G.; Ponsá, S.; Gea, T.; Artola, A.; Vázquez, F.; Sánchez, A.; Adani, F. (2009) In Search of a Reliable Technique for the Determination of the Biological Stability of the Organic Matter in the Mechanical-Biological Treated Waste. J. Hazard. Mater., 162 (2-3), 1065-1072.

Bryant, C. W.; Rich, L. G. (1984) Benthal Stabilization of Organic Carbon and Nitrogen: The Development of Interstitial Profiles. J. Water Pollut. Control Fed., 56 (11), 1199-1203. 
Chen, Y.; Higgins, M.; Murthy, S.; Maas, N.; Covert, K.; Toffey, W. (1996) Production of Odorous Indole, Skatole, p-Cresole, Toluene, Styrene, and Ethylbenzene in Biosolids. J. Residuals Sci. Technol., 3 (4), 193202.

Davis, J.; Reynolds, J.; Miller, I.; Katupitiya, S. (2008) Odours from Biosolids-the Relationship with Stability: Phase II Inconsistency between indicators for both aerobic and anaerobic products. Water, 35 (6), 70-74.

Frølund, B.; Palmgren, R.; Keiding, K.; Nielsen, P. H. (1996) Extraction of Extracellular Polymers from Activated Sludge Using a Cation Exchange Resin. Water Res., 30 (8), 1749-1758.

Glindemann, D.; Murthy, S.; Higgins, M.; Chen, Y.; Novak, J. (2006) Biosolids Incubation Method for Odorous Gas Measurement from Dewatered Sludge Cakes. J. Residuals Sci. Technol., 3 (3), 153-160.

Hall, G. M. (1996) Methods of Testing Protein Functionality. Springer, Blakie Academic and Professional: London, England, United Kingdom.

Haug, R. T. (1993) The Practical Handbook of Compost Engineering; CRC Press: Boca Raton, Florida.

Higgins, M. J.; Chen, Y.; Yarosz, D. P.; Murthy, S. N.; Maas, N. A.; Glindemann, D.; Novak, J. T. (2006) Cycling of Volatile Organic Sulfur Compounds in Anaerobically Digested Biosolids and its Implications for Odors. Water Environ. Res., 78 (3), 243-252.

Lasaridi, K. E.; Stentiford, E. I. (1998) A Simple Respirometric Technique for Assessing Compost Stability. Water Res., 32 (12), 3717-3723.

Lay, J.; Li, Y.; Noike, T. (1997) Influences of pH and Moisture Content on the Methane Production in High-Solids Sludge Digestion. Water Res., 31 (6), 1518-1524.

Lerch, R. N.; Barbarick, K. A.; Azari, P.; Sommers, L. E.; Westfall, D. G. (1993) Sewage Sludge Proteins: I. Extraction Methodology. J. Environ. Qual., 22, 620-624.

Lomans, B. P.; van der Drift, C.; Pol, A.; Op den Camp, H. J. M. (2002) Microbial Cycling of Volatile Organic Sulfur Compounds. Cell Mol. Life. Sci., 59 (4), 575-588.

Lowry, O. H.; Rosebrough, N. J.; Farr, A. L.; Randall, R. J. (1951) Protein Measurement with the Folin Phenol Reagent. J. Biol. Chem., 193 (1), 265-275.

Nelson, K. L.; Cisneros, B. J.; Tchobanoglous, G.; Darby, J. L. (2004) Sludge Accumulation, Characteristics, and Pathogen Inactivation in Four Primary Waste Stabilization Ponds in Central Mexico. Water Res., 38 (1), 111-127.
Paing, J.; Picot, B.; Sambuco, J.; Rambaud, A. (2000) Sludge Accumulation and Methanogenic Activity in an Anaerobic Lagoon. Water Sci. Technol., 42 (10-11), 247-255.

Ponsa, S.; Gea, T.; Sanchez, A. (2010) Different Indices To Express Biodegradability In Organic Solid Wastes. J. Environ. Qual., 39 (2), 706-712.

Reimers, R. S.; Little, M. D.; Akers, T. G.; Henriques, W. D.; Badeaux, R. C.; McDonnell, D. B.; Mbela, K. K. (1990) Persistence of Pathogens in Lagoon-Stored Sludge. U.S. Environmental Protection Agency, Risk Reduction Engineering Laboratory: Cincinnati, Ohio

Rittmann, B. E.; McCarty, P. L. (2001) Environmental Biotechnology; McGraw-Hill: New York.

Rosenfeld, P. E.; Suffet, I. H. (2004) Understanding Odorants Associated With Compost, Biomass Facilities, and Land Application of Biosolids. Water Sci. Technol., 49 (9), 193-199.

Schievano, A.; Pognani, M.; D'Imporzano, G.; Adani, F. (2008) Predicting Anaerobic Biogasification Potential of Ingestates and Digestates of a Full-Scale Biogas Plant Using Chemical and Biological Parameters. Bioresour. Technol., 99 (17), 8112-8117.

Schneiter, R. W.; Middlebrooks, E. J.; Sletten, R. S.; Reed, S. C. (1993) Sludge from Cold Regions Lagoons. Water Environ. Res., 65 (2), 146-155.

Switzenbaum, M. S.; Moss, L. H.; Epstein, E.; Pincince, A. B.; Donovan, J. F. (1997) Defining Biosolids Stability. J. Environ. Eng., 123 (12), $1178-1184$

Tata, P.; Lue-Hing, C.; Bertucci, J. J.; Sedita, S. J.; Knafl, G. J. (2000) Class A Biosolids Production by a Low-Cost Conventional Technology. Water Environ. Res., 72 (4), 413-422.

Tata, P.; Lue-Hing, C.; Sawyer, B.; Lanyon, R.; Farnan, J. C. (2003) How Chicago Obtained and Will Benefit from Site-Specific PFRP Certification. Proceedings of the 76th Annual Water Environment Federation Technical Exposition and Conference [CD-ROM]; Los Angeles, California, Oct 11-15; Water Environment Federation: Alexandria, Virginia.

Tchobanoglous, G.; Burton, F.; Stensel, H. (2002) Wastewater Engineering: Treatment and Reuse, 4th ed.; McGraw-Hill: New York.

U.S. Environmental Protection Agency (1993a) 40 CFR Part 503: Standards for the Use and Disposal of Sewage Sludge. Fed. Reg., 58, 9248.

U.S. Environmental Protection Agency (1993b) Methods for the Determination of Inorganic Substances in Environmental Samples; U.S. Environmental Protection Agency: Washington, D.C. 